\title{
ANALISIS PEMAHAMAN MAHASISWA PENDIDIKAN KIMIA TENTANG MATERI ISOMERI SENYAWA KARBON
}

\author{
Kriesna Kharisma Purwanto ${ }^{1}$, AH. Fathul Jadid Anshori ${ }^{2}$ \\ Universitas Billfath
}

\section{INFO ARTIKEL}

Diterima: 19-12-2020

Disetujui: 4-2-2021

\section{Kata Kunci:}

Pemahaman Konsep;

Isomeri senyawa karbon;

Kimia Organik;

Kesulitan Belajar

\begin{abstract}
Abstrak: Penelitian ini bertujuan untuk menganalisis tingkat pemahaman mahasiswa materi isomeri senyawa organik. Rancangan penelitian yang digunakan adalah kualitatif deskriptif. Subjek penelitian adalah mahasiswa program studi Pendidikan Kimia Angkatan 2018. Objek penelitian adalah mata kuliah Kimia Organik I materi isomeri senyawa karbon. Ada 3 (tiga) tahapan dalam pengumpulan data, yaitu tes awal (pretest), pelaksanaan pembelajaran, dan tes akhir (postest). Hasil penelitian menunjukkan bahwa masih ada 2 (dua) konsep dalam materi isomeri senyawa karbon yang belum mencapai ketuntasan maksimal, yaitu jenis gugus fungsi senyawa karbon dan tipe reaksi senyawa karbon.
\end{abstract}

\begin{abstract}
This study aims to analyze the understanding level of students' in organic compound isomerism material. The research design used is descriptive qualitative. The research subjects were students of the Chemistry Education program in class 2018. The object of research was the Organic Chemistry course I, carbon compound isomerization material. There are 3 (three) stages in data collection, namely the initial test (pretest), implementation of learning, and the final test (posttest). The results showed that there are still 2 (two) concepts in the isomeric material of carbon compounds that have not reached maximum completeness, namely the type of carbon compound functional group and the type of carbon compound reaction.
\end{abstract}

Alamat Korespondensi

$\begin{array}{ll}\text { Nama } & : \text { Kriesna Kharisma Purwanto } \\ \text { Instansil } & : \text { Pendidikan Kimia, Universitas Billfath } \\ \text { Alamat instansi } & : \text { Kompleks PP Al Fattah, Desa Siman, Kecamatan Sekaran, Kabupaten } \\ & \text { Lamongan, Jatim } \\ \text { Surel } & : \text { vegaku87@gmail.com }\end{array}$

Materi isomeri molekul pada mata kuliah Kimia Organik I merupakan konsep dasar untuk mempelajari materi gugus fungsi pada mata kuliah Kimia Organik II. Ketika mahasiswa telah mampu menguasai materi isomeri senyawa karbon, maka mereka akan lebih mudah untuk memahami deskripsi golongangolongan senyawa organik. Dengan demikian, pemahaman mahasiswa tentang isomeri senyawa karbon berpengaruh terhadap keberhasilan dalam pembelajaran Kimia Organik II. Jika mahasiswa mengalami kesulitan mempelajari konsep dasar tersebut, maka mereka cenderung akan mengalami kesulitan dalam pembelajaran Kimia Organik II.

Berdasarkan hasil observasi awal, nilai rata-rata mahasiswa pada mata kuliah Kimia Organik I sebesar 65,7 dan nilai rata-rata mahasiswa pada materi 2 isomer senyawa organik sebesar 53,96. Hasil tersebut mengindikasikan bahwa mahasiswa masih mengalami kesulitan dalam memahami materi isomeri senyawa organik. Hasil wawancara dengan mahasiswa yang telah menempuh mata kuliah Kimia Organik I menunjukkan bahwa ternyata mereka masih mengalami kesulitan dalam memahami konsep isomeri geometri, terutama pada konsep isomeri optik dan penentuan konfigurasi (R/S). Kesulitan belajar tersebut disebabkan oleh mahasiswa masih kesulitan dalam memahami konsep geometri molekul.

Penelitian terdahulu oleh Fitriana, dkk (2014) juga menyebutkan bahwa hasil belajar siswa pada materi isomer dan reaksi senyawa karbon masih rendah, yaitu 65,45 (di bawah KKM) dengan persentase ketuntasan hasil belajar 39,47\%. Siswa mengalami kesulitan dalam 
meramalkan isomer dari suatu senyawa dan masih sulit untuk membedakan jenis reaksi, memberikan contoh reaksi, dan meramalkan hasil reaksi pada senyawa karbon. Jika pada level sekolah menengah siswa masih mengalami kesulitan tersebut, maka tidak menutup kemungkinan bahwa kesulitan tersebut akan tetap berlanjut di level perguruan tinggi. Hal ini sejalan dengan hasil penelitian dari Suja (2015:623) yang menunjukkan bahwa (1) mahasiswa calon guru kimia masih mengalami kesulitan dalam memahami konsep stereokimia dimana mahasiswa ada yang tidak paham konsep $(20,71 \%)$, mengalami miskonsepsi spesifik $(33,04 \%)$, memiliki konsep alternatif $(12,50 \%)$, dan memiliki konsep dengan benar secara ilmiah $(33,75 \%)$, (2) mahasiswa mengalami miskonsepsi tertinggi $(92,86 \%)$ pada ko ep penentuan konfigurasi (R/S) senyawa berdasarkan proyeksi Newman, serta (3) mahasiswa memiliki konsep alternatif tertinggi $(32,14 \%)$ yaitu pada penggambaran proyeksi Fischer stereoisomer yang diketahui konfigurasi absolutnya. Penelitian selanjutnya oleh Djarwo (2019:94-95) juga menunjukkan bahwa mahasiswa masih mengalami miskonsepsi pada materi isomer, yaitu tentang isomeri senyawa alkana $(20,83 \%)$, jumlah isomer $(37,50 \%)$, isomer senyawa alkena $(20,83 \%)$, isomer posisi $(4,17 \%)$, isomer rantai $(8,33 \%)$, isomer geometri $(20,83 \%)$, dan isomer senyawa alkuna $(12,50 \%)$.

Untuk mengantisipasi hal tersebut pada semester selanjutnya, maka peneliti ingin melakukan analisis pemahaman mahasiswa terhadap konsep isomeri senyawa karbon, sehingga dosen dapat mengetahui kesulitan belajar yang dialami oleh mahasiswa. Dengan demikian, dengan adanya hasil analisis pemahaman dasar tersebut, maka dosen dapat menentukan dan/atau memperbaiki model dan strategi pembelajaran apa yang tepat untuk mata kuliah Kimia Organik I.

\section{METODE}

Rancangan penelitian yang digunakan dalam penelitian ini adalah kualitatif deskriptif, yaitu rancangan penelitian yang berusaha untuk mendeskripsikan suatu gejala peristiwa atau kejadian secara sistematis dan akurat serta mendalam. Penelitian telah dilaksanakan pada tanggal 1 November 2019 s.d 31 Januari 2020 pada Semester Ganjil Tahun Akademik 2019/2020. Subjek penelitian adalah mahasiswa Program Studi Pendidikan Kimia Angkatan 2018. Objek penelitian adalah mata kuliah Kimia Organik I materi isomeri senyawa karbon .

Ada 3 (tiga) tahapan dalam pengumpulan data ini, yaitu tes awal (pretest), pelaksanaan pembelajaran, dan tes akhir (postest). Pretest bertujuan untuk memperoleh data pengetahuan awal mahasiswa mengenai materi yang akan dipelajari. Pada tahap pelaksanaan pembelajaran dilakukan selama 100 menit berdasarkan RPS yang sudah dibuat. Posttest dilakukan setelah pembelajaran dan bertujuan untuk mengukur tingkat pemahaman mahasiswa pada materi yang telah diajarkan.

Pengumpulan data dalam penelitian ini dilakukan dengan menggunakan instrument tes yang diberikan kepada mahasiswa kemudian hasilnya dianalisis untuk mengetahu pemahaman konsep mahasiswa, Soal terdiri atas 5 soal dan pada masing-masing soal ada anak nomor tambahan. Data yang diperoleh dari instrument tes kemudian dianalisis untuk masing-masing perubahan konsep yang dialami oleh mahasiswa.

\section{HASIL}

\section{Deskripsi Pemahaman Awal}

Pemahaman awal mahasiswa diperoleh berdasarkan hasil tes awal (pretest) menggunakan soal uraian. Berdasarkan hasil tes tersebut, peneliti menemukan bahwa semua mahasiswa masih memiliki pemahaman awal yang sangat kurang untuk materi isomeri senyawa karbon. Kurangnya pemahaman awal ini disebabkan adanya kesulitan dalam memahami konsep isomeri senyawa karbon. 
KARANGAN: Jurnal Kependidikan, Pembelajaran, dan Pengembangan, Vol 03, No 01, Bulan Februari, Tahun 2021, Hal 26-35

\section{Deskripsi Pelaksanaan Pembelajaran}

Situasi kelas saat penelitian cukup terkendali, dimana mahasiswa berpartisipasi dengan baik selama penelitian berlangsung. Mahasiswa cukup senang dan antusias dalam mengikuti pembelajaran, dapat dilihat saat mengerjakan soal pretest kemudian mengikuti pembelajaran dan mengerjakan soal postest semuanya dilakukan dengan bersungguh-sungguh dan bersemangat. Semua mahasiswa yang berpartisipasi memberikan sikap yang baik saat dilaksanakannya penelitian ini.

\section{Pemahaman Akhir}

Pemahaman akhir mahasiswa diperoleh berdasarkan hasil tes akhir (posttest) menggunakan soal berbentuk uraian yang juga digunakan dalam tes awal (prestest). Berdasarkan hasil tes tersebut, peneliti melakukan konfirmasi terkait jawaban mahasiswa pada setiap item soal untuk mengetahui perubahan pemahaman konsep isomeri senyawa karbon setelah pembelajaran. Butir soal beserta poin dalam masing-masing soal yang digunakan untuk tes akhir (posttest) disajikan pada Tabel 1 sebagai berikut.

Tabel 1. Soal Tes Akhir (Posttest)

Item Soal Posttest
2. Identifikasi semua gugus fungsi yang terdapat dalam senyawa berikut.
2. Tulis rumus struktur untuk senyawa berikut.
a. Alkohol tersier dengan rumus $\mathrm{C}_{5} \mathrm{H}_{12} \mathrm{O}$
b. Ester dengan rumus $\mathrm{C}_{5} \mathrm{H}_{10} \mathrm{O}_{2}$
c. Asam karboksilat dengan rumus $\mathrm{C}_{3} \mathrm{H}_{6} \mathrm{O}_{2}$
d. Aldehida dengan rumus $\mathrm{C}_{4} \mathrm{H}_{8} \mathrm{O}_{2}$
e. Amina primer dengan rumus $\mathrm{C}_{5} \mathrm{H}_{13} \mathrm{~N}$

3. Berikan contoh pasangan senyawa yang merupakan:
a. Isomer gugus fungsi 5
b. Isomer posisi
15 poin
c. Isomer rantai

4. Tentukan konfigurasi $(\mathrm{R} / \mathrm{S})$ dari senyawa berıkut.

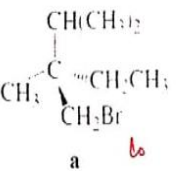

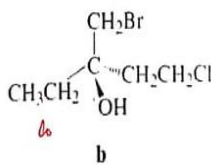

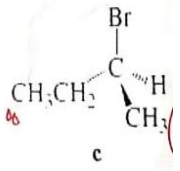
30 poin

5. Tentukan tipe reaksi untuk masing-masing persamaan reaksi berikul beserta alasannya!
a. $\mathrm{CH}_{3} \mathrm{CH}=\mathrm{CHCH}_{3}+\mathrm{HBr}_{3} \rightarrow \mathrm{CH}_{3} \mathrm{CH}_{3}\left(\mathrm{Br}_{\mathrm{C}} \mathrm{CH}_{2} \mathrm{CH}_{3}\right.$
b. $\mathrm{HBr}+\mathrm{H}_{2} \mathrm{O} \rightarrow \mathrm{H}_{3} \mathrm{O}^{+}+\mathrm{Br}$

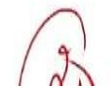
20 poin 
KARANGAN: Jurnal Kependidikan, Pembelajaran, dan Pengembangan, Vol 03, No 01, Bulan Februari, Tahun 2021, Hal 26-35

Berdasarkan hasil tes mahasiswa, peneliti melakukan konfirmasi terkait jawaban mahasiswa pada setiap item soal untuk mengetahui perubahan pemahaman konsep isomeri senyawa karbon setelah pembelajaran. Hasil jawaban mahasiswa pada tes akhir (posttest) disajikan pada Tabel 2 sebagai berikut.

Tabel 2. Jawaban Tes Akhir (Posttest)

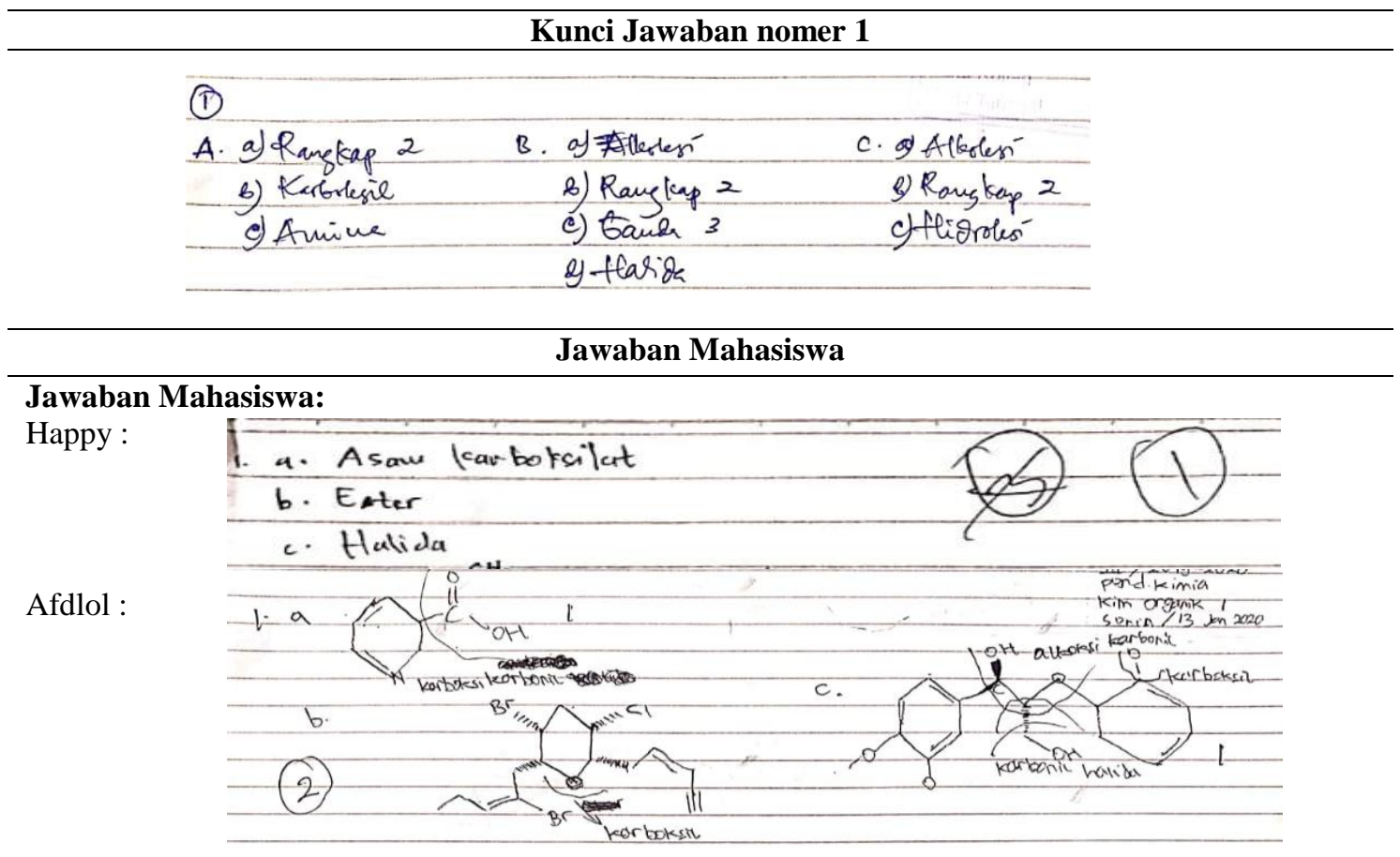

Fina :

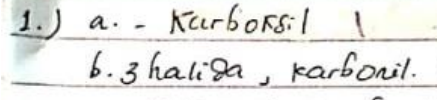

Qonik :

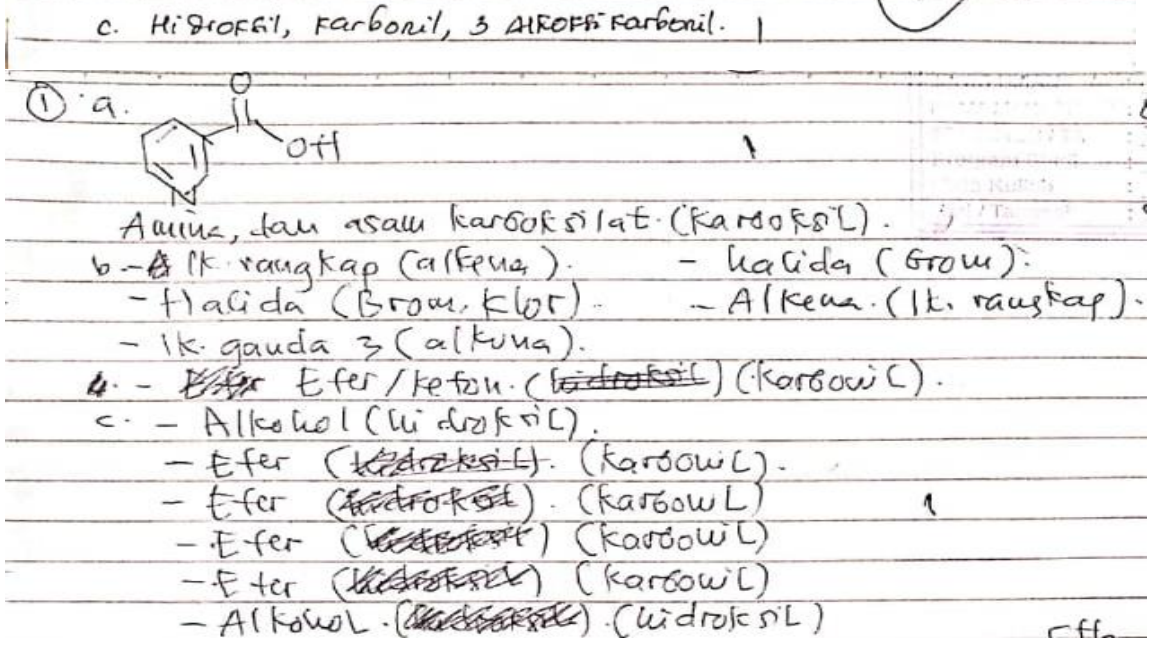

Lista :

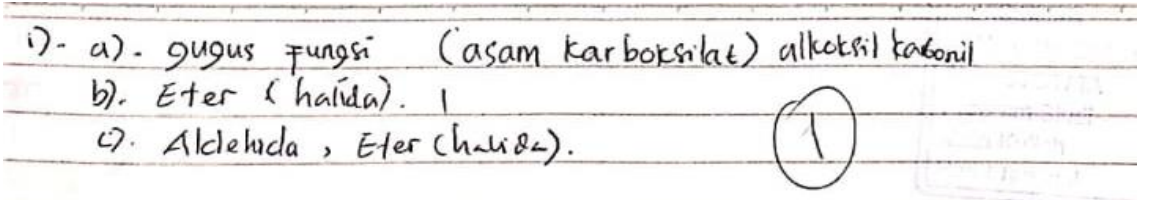


KARANGAN: Jurnal Kependidikan, Pembelajaran, dan Pengembangan, Vol 03, No 01, Bulan Februari, Tahun 2021, Hal 26-35

\section{Kunci Jawaban nomer 2}

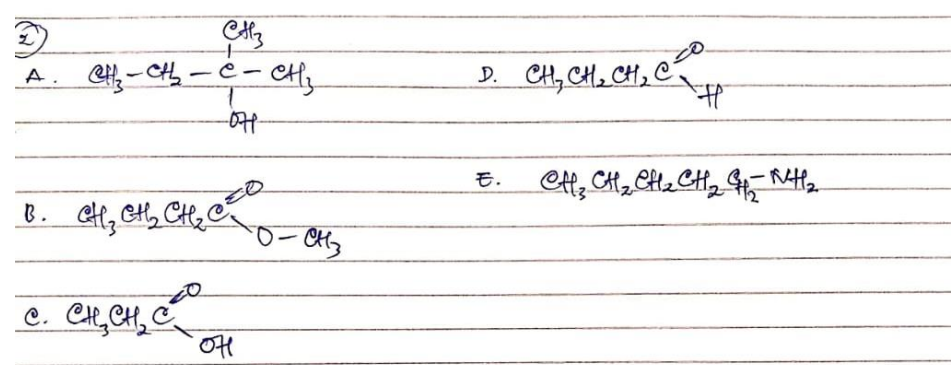

\section{Jawaban Mahasiswa:}

Happy :
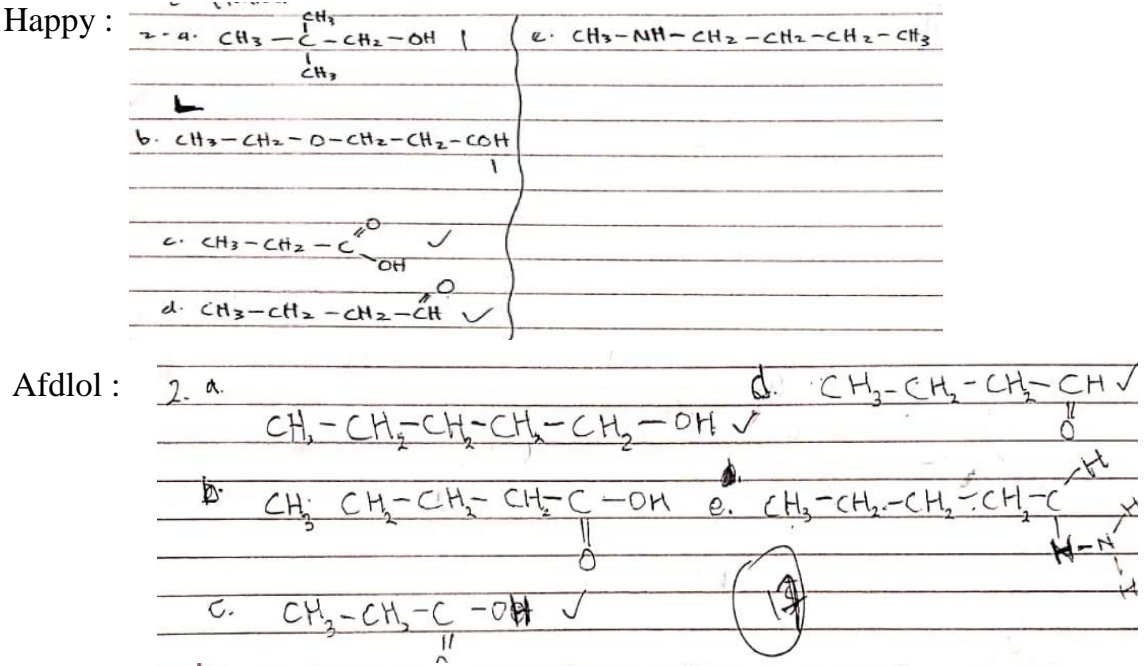

$$
\begin{aligned}
& \text { Fina: 2) a. } \mathrm{C}_{5} \hat{\mathrm{H}}_{12} \mathrm{O} \text { (alkofol dersier) } \\
& \mathrm{CH}_{3}-\mathrm{C}-\mathrm{OH} \\
& \mathrm{CH}_{1}-\mathrm{CH}_{3} \\
& \text { 6. } \mathrm{C}_{5} \mathrm{H}_{10 \mathrm{OO}} \text { (Ester) } \\
& \mathrm{CH}_{3}-\mathrm{CH}_{2}-\mathrm{CH}_{2}-\mathrm{C}_{\mathrm{O}} \mathrm{O} \\
& \mathrm{CH}_{3}-\mathrm{CH}_{2}-\mathrm{C}=\mathrm{OH} \\
& \text { 8. Algefira (ayrgo) } \\
& \mathrm{CH}_{3}-\mathrm{CH}_{2}-\mathrm{CH}_{2}-\mathrm{C}_{\mathrm{H}}- \\
& \text { e. Amena prialer }\left(\mathrm{C}_{5} \mathrm{H}_{3} \pi \mathrm{T}\right) \text {. } \\
& \mathrm{CH}_{3}-\mathrm{CH}_{2}-\mathrm{CH}_{2}-\mathrm{CH}_{2}-\mathrm{CH}_{2}-\mathrm{rH}_{2}-
\end{aligned}
$$

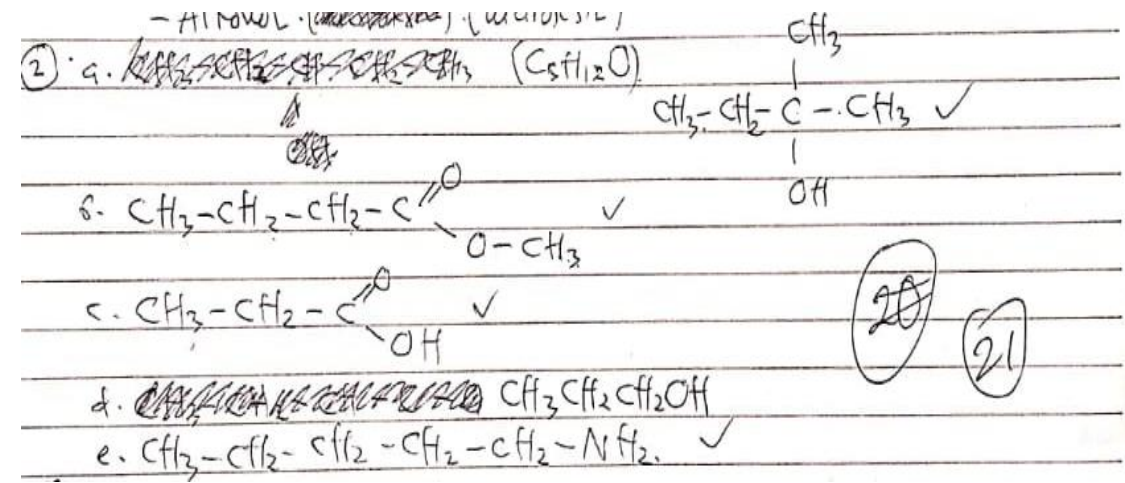


KARANGAN: Jurnal Kependidikan, Pembelajaran, dan Pengembangan, Vol 03, No 01, Bulan Februari, Tahun 2021, Hal 26-35

Lista :

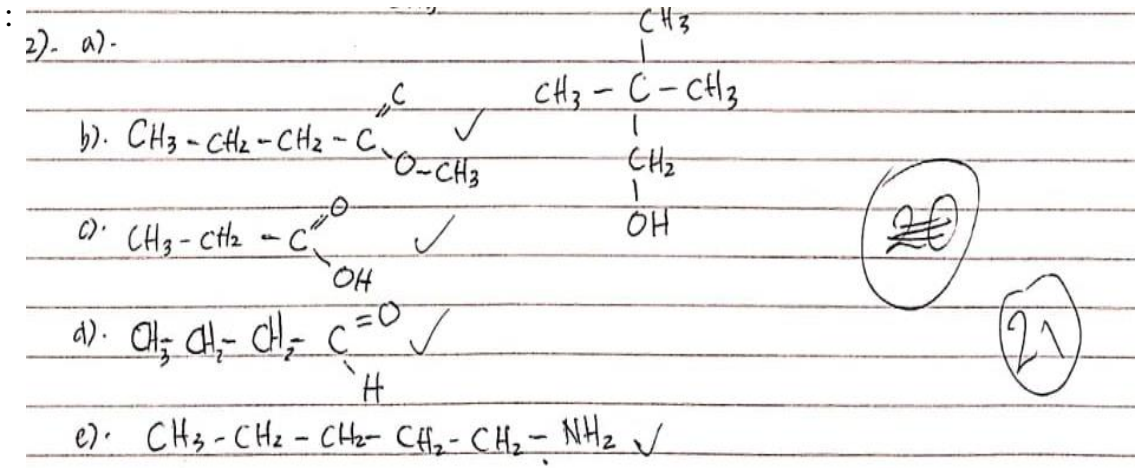

Kunci Jawaban nomer 3

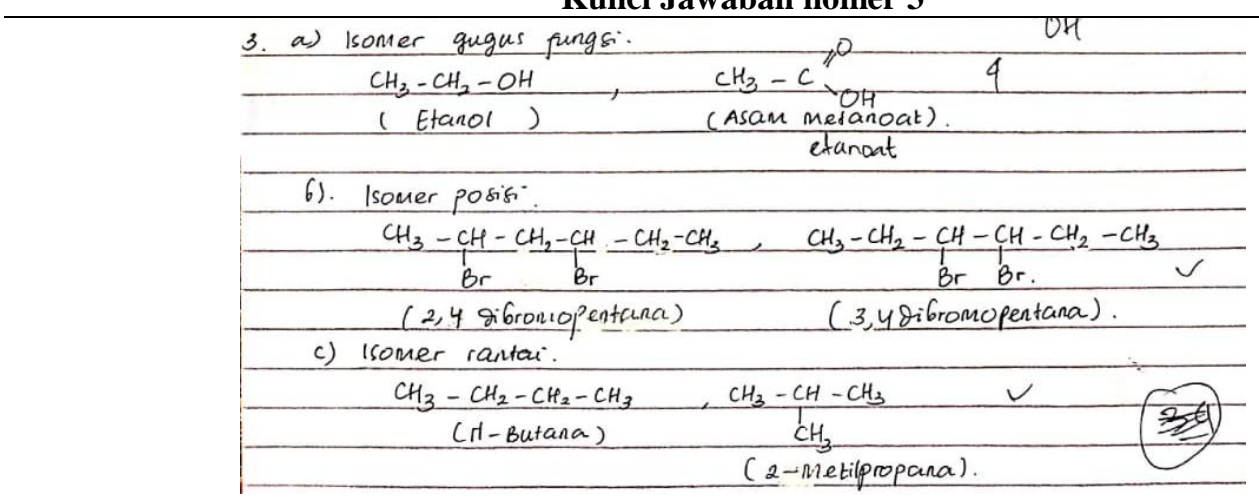

Jawaban Mahasiswa:

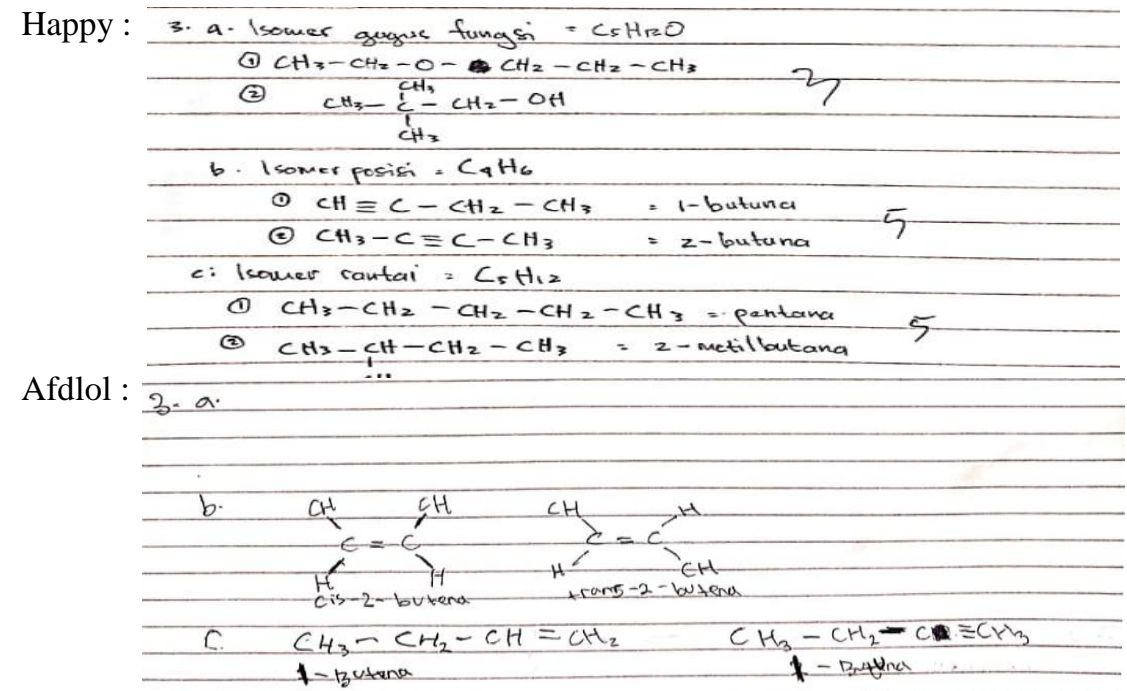

Qonik: [7]-a. (simer gugus fougs)

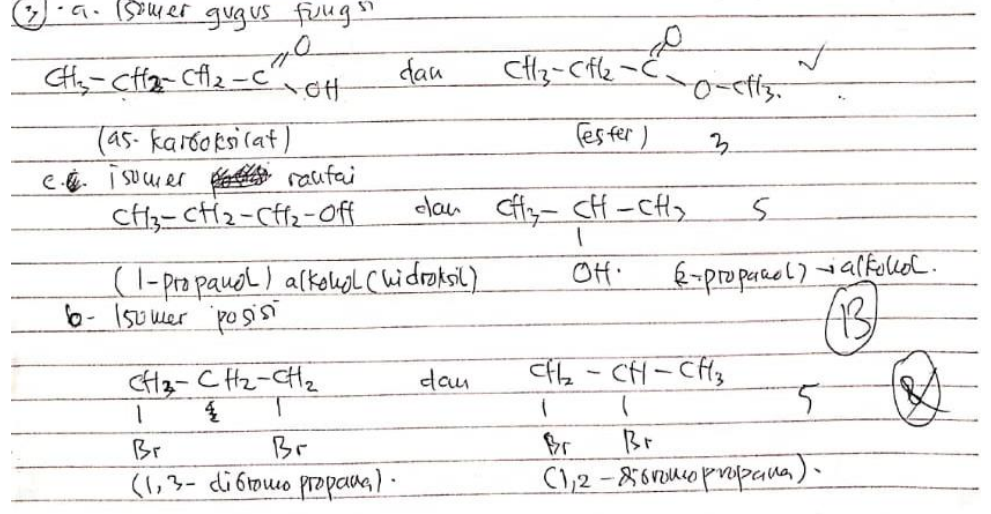


KARANGAN: Jurnal Kependidikan, Pembelajaran, dan Pengembangan, Vol 03, No 01, Bulan Februari, Tahun 2021, Hal 26-35

Lista :

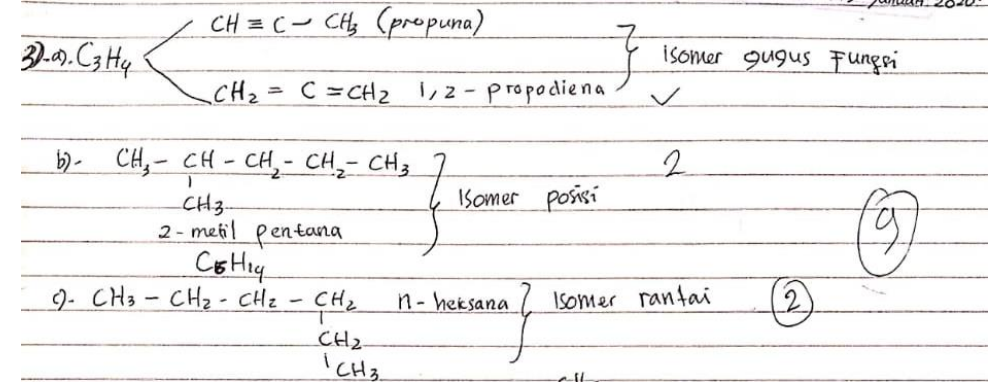

\section{Kunci Jawaban nomer 4}

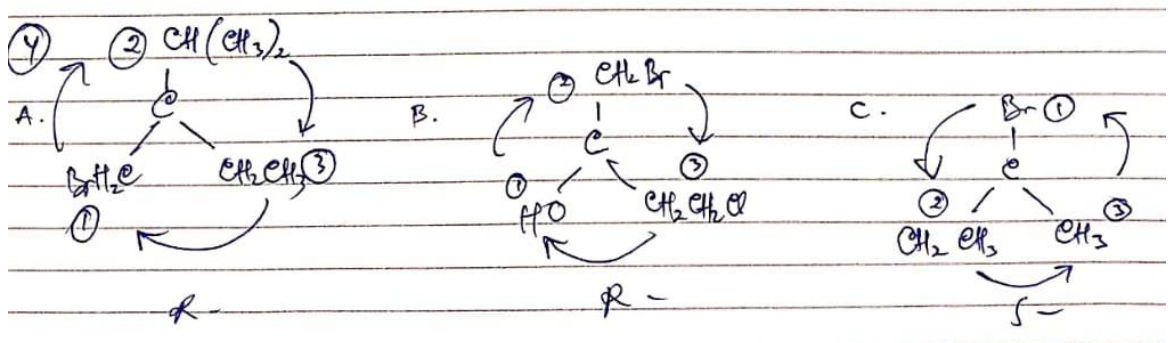

Jawaban Mahasiswa:

Happy :

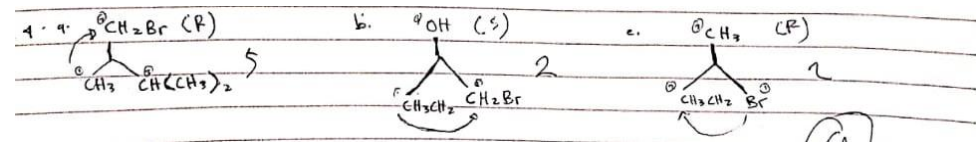

Afdlol :

4. (a) $R$
(b) $R$
(c) $S$.

Fina :

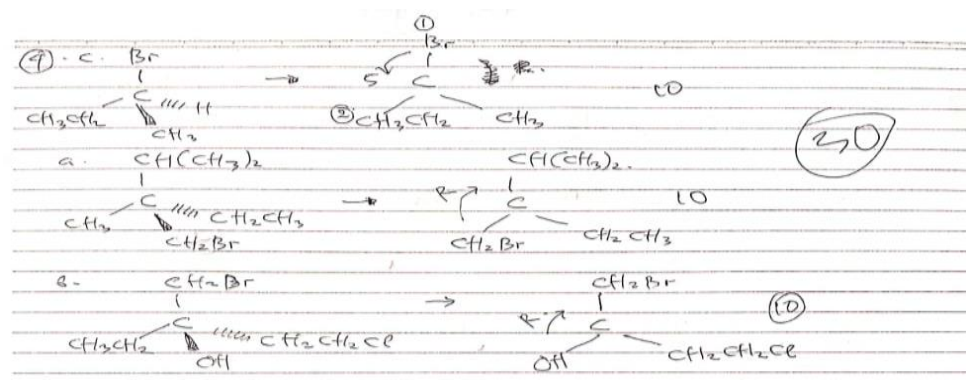

Qonik :

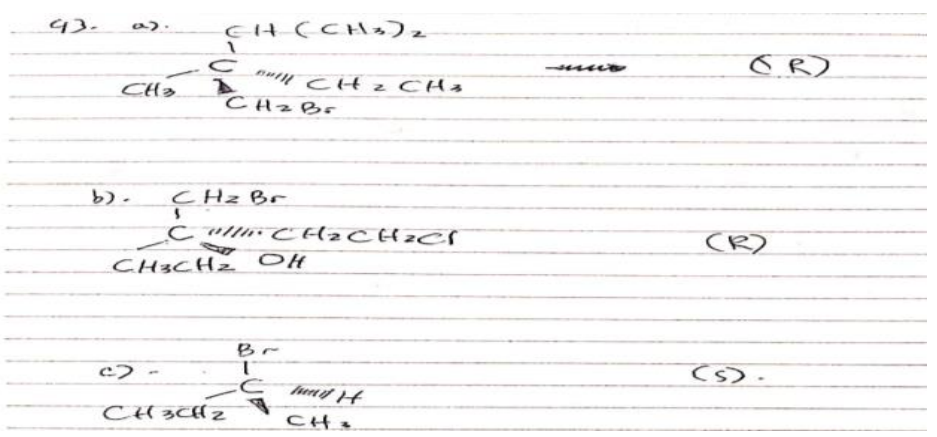

Lista : tidak menjawab 
KARANGAN: Jurnal Kependidikan, Pembelajaran, dan Pengembangan, Vol 03, No 01, Bulan Februari, Tahun 2021, Hal 26-35

Kunci Jawaban nomer 5
(5) $\mathrm{CH}_{3}-\mathrm{CH}=\mathrm{CH}-\mathrm{eH}_{3}+\mathrm{HBr} \rightarrow \mathrm{CH}_{3}-\mathrm{CH}_{-}-\mathrm{CH}_{2}-\mathrm{CH}_{3}$ (adian-)
B. $\mathrm{HBr}+\mathrm{H}_{2} \mathrm{O} \rightarrow \mathrm{H}_{3} \mathrm{O}^{+}+\mathrm{Br}^{-}$(asam basa)

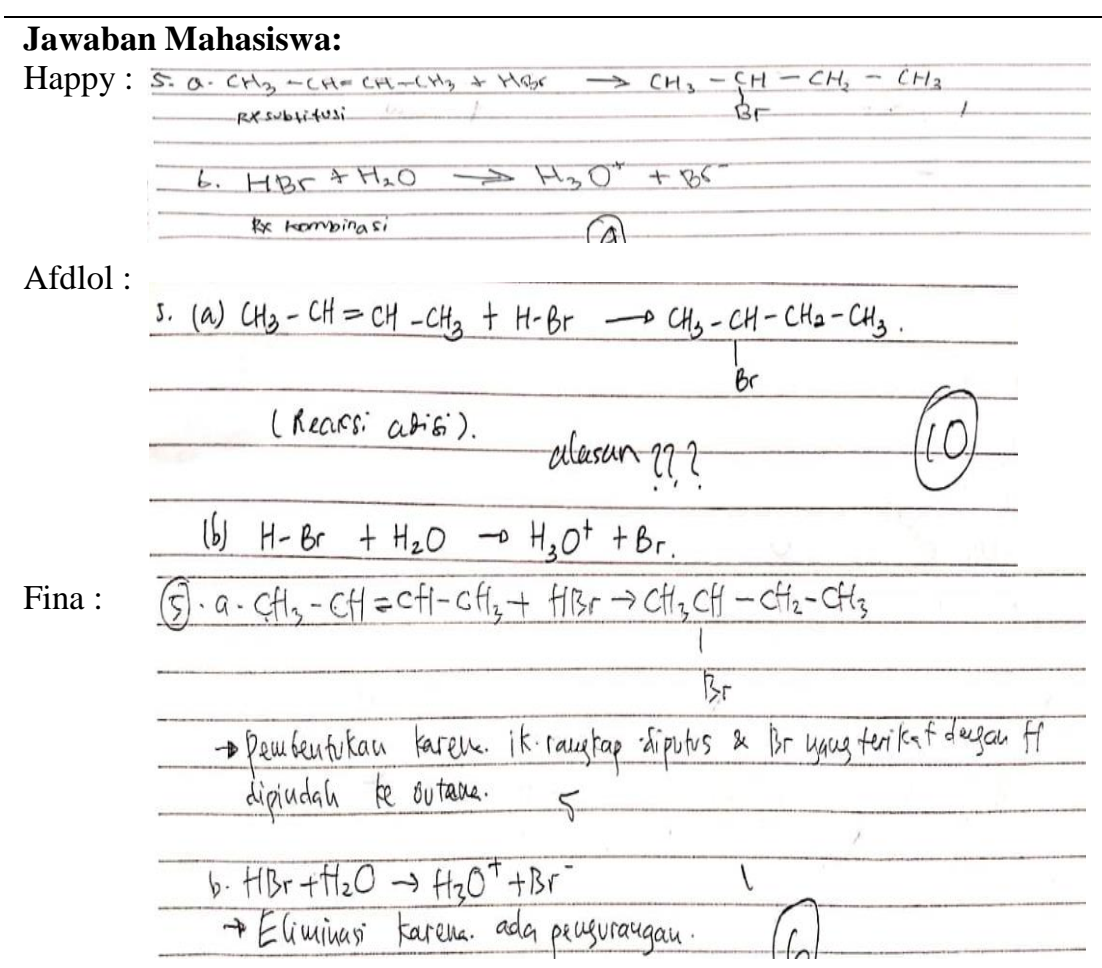

Qonik : tidak menjawab

Lista :

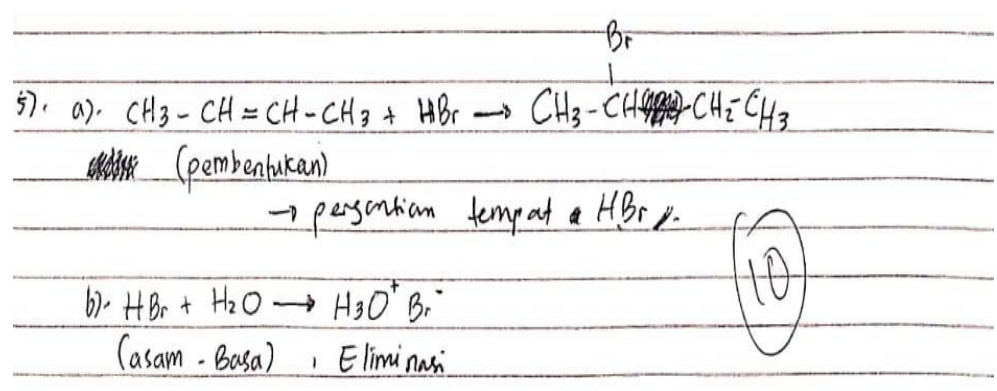

Berdasarkan hasil analisis jawaban pada Tabel 2, dapat disimpulkan bahwa terjadi perubahan pemahaman (kognitif) pada mahasiswa terkait konsep isomer senyawa karbon. Hasil di atas menunjukkan bahwa setelah pembelajaran isomer senyawa karbon, mahasiswa sudah mengalami perubahan pemahaman konsep yang lebih baik. Namun, prosentase pemahaman mahasiswa untuk semua materi masih kurang tinggi. Selain itu ada 2 (dua) konsep yang belum mencapai ketuntasan maksimal, yaitu semua mahasiswa masih belum memahami dengan baik jenis gugus fungsi dan tipe reaksi senyawa karbon. Mahasiswa masih kesulitan dalam mengenali semua gugus fungsi suatu senyawa karbon. Untuk konsep tipe reaksi, mahasiswa juga masih kesulitan dalam menentukan tipe rekasi untuk suatu reaksi. 
KARANGAN: Jurnal Kependidikan, Pembelajaran, dan Pengembangan, Vol 03, No 01, Bulan Februari, Tahun 2021, Hal 26-35

\section{PEMBAHASAN}

Analisis Pemahaman mahasiswa untuk masing-masing soal pada instrument tes dijabarkan satu persatu pada setiap nomer soal. Pada soal petama, berdasarkan data yang diperoleh diketahui bahwa seluruh mahasiswa tidak dapat menyebutkan semua gugus fungsi yang terdapat pada masing-masing senyawa yang diberikan. Namun, ada 1 mahasiswa yang mampu menyebutkan hanya 1 gugus fungsi untuk masing-masing senyawa. Hal ini menunjukkan bahwa pemahaman mahasiswa masih sangat kurang dalam pemahaman konsep gugus fungsi senyawa karbon. Hal ini bisa disebabkan karena kurangnya mahasiswa memahami konsep gugus fungsi untuk masing-masing sehingga mahasiswa tidak dapat mengenali dan membedakan amsing-masing gugus fungsi.

Analisis pemahaman mahasiswa pada soal kedua menunjukkan bahwa tidak ada mahasisawa yang mampu menjawab dengan benar, akan tetapi semua jawaban sudah hampir mendekati kebenaran. Ada 1 mahassiwa yang sudah benar dalam menuliskan semua rumus struktur senyawa namun salah dalam pemberian nama sehingga poinnya dikurangi. Sedangkan utuk soal ketiga menunjukkan bahwa $80 \%$ mahasiswa hampir menjawab dengan benar akan tetapi masih kurang tepat dalam pemberian nama isomer. Hal ini menunjukkan bahwa mahasiswa sudah memahami konsep jenis isomer akan tetapi masih kurang paham dalam penamaan isomer senyawa karbon. Ada 1 mahasiswa yang tidak menjawab lengkap. Hal ini menunjukkan bahwa pemahaman mahasiswa tersebut masih sangat kurang.

Pada soal keempat $60 \%$ mahasiswa menjawab dengan benar. Hal ini menunjukkan bahwa sebagian besar mahasiswa sudah memahami konsep konfigurasi R/S. Namun ada mahasiswa yang bisa menjawab benar akan tetapi tidak menggambarkan susunan senyawa karbon beerta konfigurasinya. Selain itu ada 1 mahasiswa yang tidak menjawab. Untuk 1 mahasiswa yang tidak menjawab ini perlu dilakukan suatu kegiata wawancara yang lebih dalam mengenai alas an tidak menjawab, namun analsisi awal adalah mahasiswa tersebut tidak paham akan konsep yang ada di soal keempat.

Pada soal terakhir yaitu soal kelima, diketahui bahwa semua mahasiswa tidak mampu menjawab dengan benar. Konsep yang ada dalam soal nomer lima ini adalah konsep jenis reaks dari dua reaksi senyawa karbon yang ditanyakan. Ada sebagian yang mampu menjawab dengan benar 1 reaksi akan tetapi reaksi yang lainnya masih salah. Selain itu ada juga mahasiswa yang tidak menjawab sama sekali. Hal ini menunjukkan bahawa pemahaman mahasiswa mengenai jenis reaksi senyawa karbon dan isomernya masih sangat kurang.

\section{SIMPULAN DAN SARAN Simpulan}

Terdapat 2 (dua) konsep dalam materi isomer senyawa karbon yang belum mencapai ketuntasan maksimal, yaitu jenis gugus fungsi senyawa karbon dan tipe reaksi senyawa karbon.

\section{Saran}

Dosen perlu memperhatikan konsep-konsep kimia yang sering kali dianggap remeh oleh mahasiswa, namun konsep tersebut harus dikuaasai dengan baik dan benar. Selain itu, dosen juga harus memilih model pembelajaran yang tepat untuk pembelajaran yang bermakna bagi mahasiswa.Ucapan Terima Kasih (Opsional)

\section{DAFTAR RUJUKAN}

Djarwo, C. F. 2019. Analisis Miskonsepsi Mahasiswa Pendidikan Kimia pada Materi Hidrokarbon. Jurnal Ilmiah IKIP Mataram, Vol. 6, No. 2, 2019, pp. 90-97.

Fitriana, I., Mulyani, S., \& Mulyani, B. 2014. Peningkatan Aktivitas dan Hasil Belajar Siswa Melalui Model Pembelajaran Activity Based Learning Berbantuan Flash Card Dilengkapi LKS pada Materi Isomer dan Reaksi Senyawa Hidrokarbon Kelas X SMA Batik 1 Surakarta Tahun Pelajaran 2012/2013. Jurnal Pendidikan Kimia Universitas Sebelas Maret, Vol. 3,No. 2, 2014, pp.88-95. 
KARANGAN: Jurnal Kependidikan, Pembelajaran, dan Pengembangan, Vol 03, No 01, Bulan Februari, Tahun 2021, Hal 26-35

Kusharyati, I. 2009. Penerapan Model Pembelajaran Kooperatif dengan Metode Jigsaw untuk Meningkatkan Penguasaan Konsep dalam Pembelajaran Akuntansi Siswa Kelas XI IS 5 SMA Negeri 8 Surakarta Tahun Ajaran 2008/2009 (Penelitian Tindakan Kelas).

Suja, I Wayan. 2015. Model Mental Mahasiswa Calon Guru Kimia Dalam Memahami Bahan Kajian Stereokimia. Jurnal Pendidikan Indonesia, Vol. 4, No. 2, 2015, pp. 623-636.

Zubaidah. 2010. Penguasaan Konsep oleh Siswa Melalui Metode PBL Pada Konsep Sistem Respirasi (Eksperimen di MTs Negeri Cipondoh Tanggerang). Skripsi dipublikasikan, UIN Syarif Hidayatullah Jakarta. 